\title{
ダッタンソバ種子への吸水処理が発芽および成長に与える影響
}

\author{
中井勇介* ${ }^{*}$ 渡辺慎一 \\ 国立研究開発法人 農業・食品産業技術総合研究機構 九州沖縄農業研究センター \\ 園芸研究領域 839-8503 福岡県久留米市御井町 1823-1
}

\section{Effect of Imbibed Seeds Treatment on Germination and Growth in Tartary Buckwheat (Fagopyrum tataricum Gaertn.)}

\author{
Yusuke NAKAI* and Shin-ichi WATANABE \\ Kyushu Okinawa Agricultural Research Center (KARC), National Agriculture and \\ Food Research Organization (NARO), 1823-1 Miimachi, Kurume, Fukuoka 839-8503, Japan
}

\begin{abstract}
Sprouts are expected to be a promising crop for closed plant factories that use artificial light, because of the fact that sprouts can be grown using only freshwater and lowlight conditions. Therefore, we focused on Tartary buckwheat (Fagopyrum tataricum Gaertn.), which has high nutritive value and is currently uncultivated as a sprout for industrial or commercial purposes. This study aimed to understand the effects of imbibition time and water temperature on germination and growth of Tartary buckwheat sprouts. The effects of imbibition time and water temperature on seed germination were evaluated by measuring variations in the coefficients of uniformity, days of germination, and germination rate. The study utilized two imbibing conditions. First, the seeds were imbibed in tap water and maintained at $25{ }^{\circ} \mathrm{C}$ for various durations $(1,3,6,8,12$, and $24 \mathrm{hr}$ ), leaving some seeds untreated as a control $(0 \mathrm{hr})$. Secondly, the seeds were imbibed in water of various temperatures $\left(4,16,20,25\right.$, and $\left.30{ }^{\circ} \mathrm{C}\right)$ for $3 \mathrm{hr}$, leaving some seeds were not imbibed in water as a control and to measure the coefficients of uniformity, days of germination, and germination rate. As a result, the coefficients of uniformity and days of germination of the seeds were improved by the imbibing treatment consisting of a water temperature of $25{ }^{\circ} \mathrm{C}$ for $3 \mathrm{hr}$ compared to the control. Furthermore, hypocotyl length and fresh weight of the sprouts tended to increase when an imbibing treatment was used in comparison to the control. On the other hand, the germination rate and dry weight of the imbibed seeds were not significantly different from those of the control seeds. Thus, our results suggest that imbibing of seeds could be effective for promoting germination and growth in Tartary buckwheat sprouts.
\end{abstract}

Keywords: Artificial light, closed plant factory, coefficients of uniformity, hypocotyl, sprouts 
方で, 光源や温度, 湿度などの環境制御に必要な電力の消 費量が多いことから, 省電力で栽培可能な作物の選定やそ れらの栽培技術の開発が求められている. スプラウト類は光 要求量が少なく水のみで栽培可能なことから, ランニングコス 卜の低減化や光強度が栽培の律速要因となる人工光型植物 工場での栽培に適合すると考えられる.

従来のかいわれ型スプラウトはかいわれ大根などアブラナ 科の野菜が主であり, ビタミン類や機能性成分の含有量の高 さが注目されている ${ }^{1-5)}$. 特に消費者の健康意識が向上して いることから, 生活習慣病などの予防効果が期待できる機能 性成分を含有する作物のスプラウト生産技術の開発が望まれ ている. そこで本研究では, 商業用にスプラウトとして栽培さ れて抢らず, 動脈硬化や脳卒中などの予防効果が報告され ているルチンや抗酸化作用が報告されているアントシアニンな どの機能性成分を含有する夕デ科ソバ属のダッタンソバ (Fagopyrum tataricum Gaertn. $)^{6)}$ に着目した. ダッタンソバス プラウトに関する先行研究として, 光照射方法と機能性成分 の蓄積に関する研究 ${ }^{7)}$ や蛍光灯などの人工光源を用いて栽 培すると子葉が展開せずに種皮が残存し成長を阻害する が, 遠赤色光を照射光に付加することで種皮脱落を促進でき ることが報告されている ${ }^{8)}$. 一方, 人工光型植物工場におい て, ダッタンソバの発芽に適した環境条件については解明され ていない. 品目を問わずスプラウ卜類を生産するには, 発芽率 や発芽の斉一性の高い栽培技術の開発が重要になる. ダイ ズでは, 種子に吸水処理を行うと発芽率や初生葉発生が良 好になると報告されている ${ }^{9)}$. そこで本報告では, 人工光型 植物工場に打いてダッタンソバスプラウトの生産技術を開発す るため, ダッタンソバの発芽に好適な種子への吸水処理方法 の検討を行った.

\section{材料および方法}

\section{1. 供試品種および栽培条件}

本研究は農研機構九州沖縄農業研究センター園芸研究 領域（福岡県久留米市）の人工光型植物工場内で行っ た. 供試品種は農研機構育成品種 ‘満天きらり’ (中原採種 場株式会社）を用いた. 播種用の培地は Kitazaki ら ${ }^{8)}$ や渡 辺らの報告 ${ }^{10)}$ を参考に, 約 $0.0125 \mathrm{~g} \mathrm{ml}^{-1}$ に調整したバージ ンパルプ培地（商品名：エコ培地，日本スプラウト協会）を 25 穴セルトレイ（1穴 $50 \mathrm{~mm}$ 角 × 深さ $50 \mathrm{~mm}$ ) の 1 セルに $50 \mathrm{ml}$ 充填し形成したものを用いた（培地の平均含水量 $9.58 \mathrm{~g})$.

栽培は渡辺ら ${ }^{10)}$ の報告を参考に以下の条件で行った. 種 子表面を水道水により約 3 分間流水洗浄した後, 水温 $25^{\circ} \mathrm{C}$ の微酸性電解水 (微酸性電解水生成装置 PURESTER ミ
ユークリーン II, 森永乳業（株））に 1 時間浸漬し殺菌処理 を行った. 種子への吸水処理は約 $4000 \mathrm{ml}$ の水道水を用い て各試験の所定の条件で行った. 種子の吸水処理中は遮光 し各処理区で設定した水温が $\pm 0.5{ }^{\circ} \mathrm{C}$ 範囲内になるよう維 持した. 種子への吸水処理時間は, 微酸性電解水による 1 時間の殺菌処理を含めた時間とした. 播種は種子への吸水 処理終了後, 直ちに行った. また, 流水洗浄抢よび殺菌処理 を行わず, 室温 $25^{\circ} \mathrm{C}$, 暗条件の人工光型植物工場内の栽 培室に 24 時間静置した未吸水処理区（対照）を設けた. 播種後の栽培は, 温度 $25^{\circ} \mathrm{C}$, 相刘湿度 $75 \%$, セルトレイ上 面の光合成有効光量子束密度 (PPFD) 約 $70 \mu \mathrm{mol} \mathrm{m}^{-2}$ $\mathrm{s}^{-1}$ の条件で 8 日間行った. 潅水は播種 24 時間経過後から 栽培 7 日目まで, 1 日 2 回 (9 時㧍よび 21 時), 5 分間, 底面 給水を行った. 光源は $\mathrm{Hf}$ 三波長（昼白色）蛍光灯（FHF $32 \mathrm{EX}-\mathrm{N}-\mathrm{PD}$, 東芝ライテック (株)）抽び子葉の展開を促 進するため遠赤色蛍光灯 (FL20S-FR-74:FR-FL, 東芝ラ イテック (株)）を併用照射した。

\section{2. 種子への吸水処理時間が発芽に与える影響}

ダッタンソバ種子を水温 $25^{\circ} \mathrm{C}$ で 1 時間, 3 時間, 6 時間, 8 時間, 12 時間および 24 時間吸水处理する区ならびに未吸 水処理区（対照）を設けた. 1 時間の区は $25^{\circ} \mathrm{Cに}$ 調整した 微酸性電解水による殺菌処理のみとした. また, 各区間で播 種が同時になるよう, 種子への吸水処理の開始時間を調整し た. 発芽の評価は Ranal and De Santana ${ }^{11)}$ や中村ら ${ }^{12)}$ の 報告を参考に発芽速度の指標である平均発芽日数, 発芽勢 の指標である斉一発芽係数, 発芽力の指標である最終発芽 率を下記に示した計算式により求めた. 平均発芽日数は播種 した日数と調査日ごとの発芽種子数から算出した. 斉一発芽 係数は播種日から 1 日ごとに発芽数を計測し 8 日間の調査結 果から算出した. 最終発芽率は栽培試験の最終日である 8 日 目の総発芽数から計算した. 本試験では, 1 セル当りにダッタ ンソバ種子を 35 粒播種し, 5 セル分の調査を 1 反復として異 なる播種日で 3 回繰り返した (1 区合計 175 粒, 3 反復).

- 平均発芽日数 $(\mathrm{GD})=\Sigma(\mathrm{d} \times \mathrm{n}) / \Sigma \mathrm{n}$

·斉一発芽係数 $=\Sigma \mathrm{n} / \Sigma\left((\mathrm{GD}-\mathrm{d})^{2} \times \mathrm{Xi}\right)$

-最終発芽率 $=(\Sigma \mathrm{Xi} / \mathrm{N}) \times 100$

$\mathrm{d}$ : 播種後日数, $\mathrm{n}: \mathrm{d}$ 日目に扔每発芽数

$\mathrm{Xi}: \mathrm{i}$ 日目の発芽種子数, $\mathrm{N}$ : 総播種数

3. 種子への吸水時の水温がダッタンソバの発芽に与える影 響

水温を $4{ }^{\circ} \mathrm{C}, 16{ }^{\circ} \mathrm{C}, 20{ }^{\circ} \mathrm{C}, 25^{\circ} \mathrm{C}$ および $30^{\circ} \mathrm{C}$ 調整し, 3 時間種子に吸水処理する区を設けた。発芽は上記同様に斉 一発芽係数, 平均発芽日数, 最終発芽率を評価した. 本試 験は 1 セル当りにダッタンソバ種子を 35 粒播種し, 5 セル分 の調査を 1 反復として異なる播種日で 3 回繰り返した. 
4. 種子への吸水処理が 8 日後のダッタンソバスプラウトの成 長に与える影響

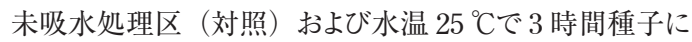

吸水処理した後に栽培する区を設け, ダッタンソバスプラウト の下肧軸長, 新鮮重, 乾物重を測定した. 下肧軸長は発芽 したすべての個体をノギスで測定しセルごとに平均值を算出
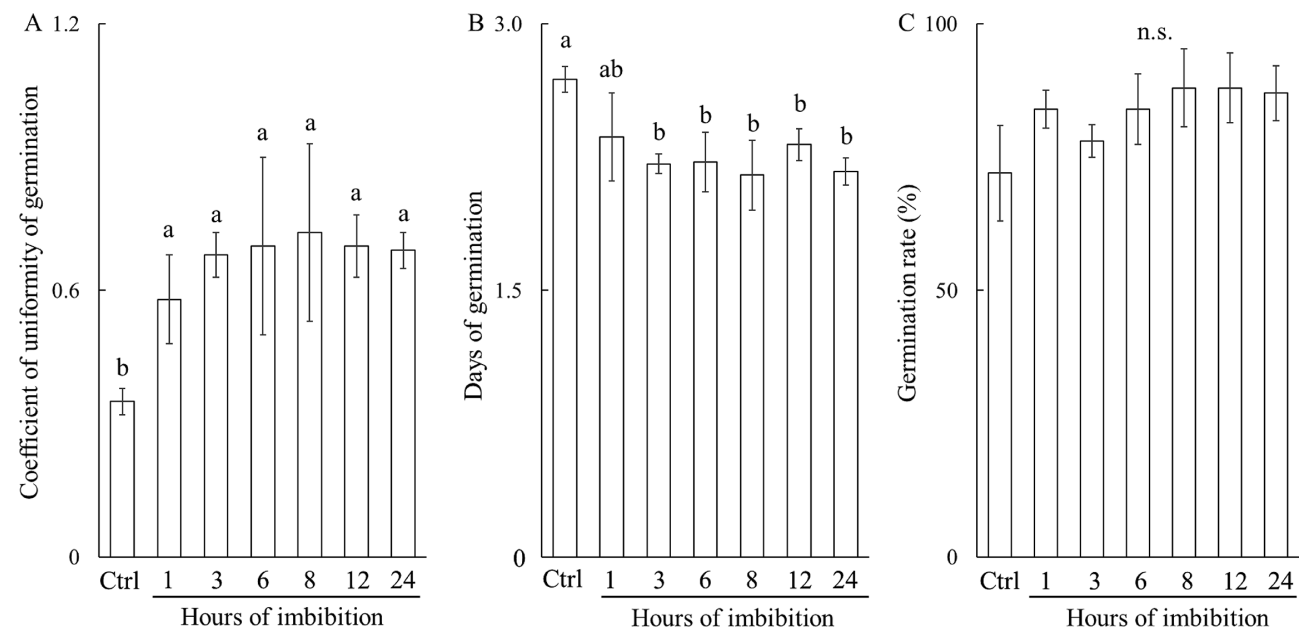

Fig. 1 Changes in the germination of Tartary buckwheat seeds for several imbibition times.

Changes in the coefficients of uniformity (A), days of germination (B), and germination rate (C) of Tartary buckwheat seeds. Tartary buckwheat seeds were imbibed at $25{ }^{\circ} \mathrm{C}$ for various durations $(1,3,6,8,12$, and $24 \mathrm{hr})$. Ctrl indicates control that was not applied imbibition treatment. Vertical bars indicate SD. Different letters indicate significant differences among treatments $(P<0.05$, Tukey HSD test $)$, and n.s. indicates no significant difference. Experiments were performed at least three times.
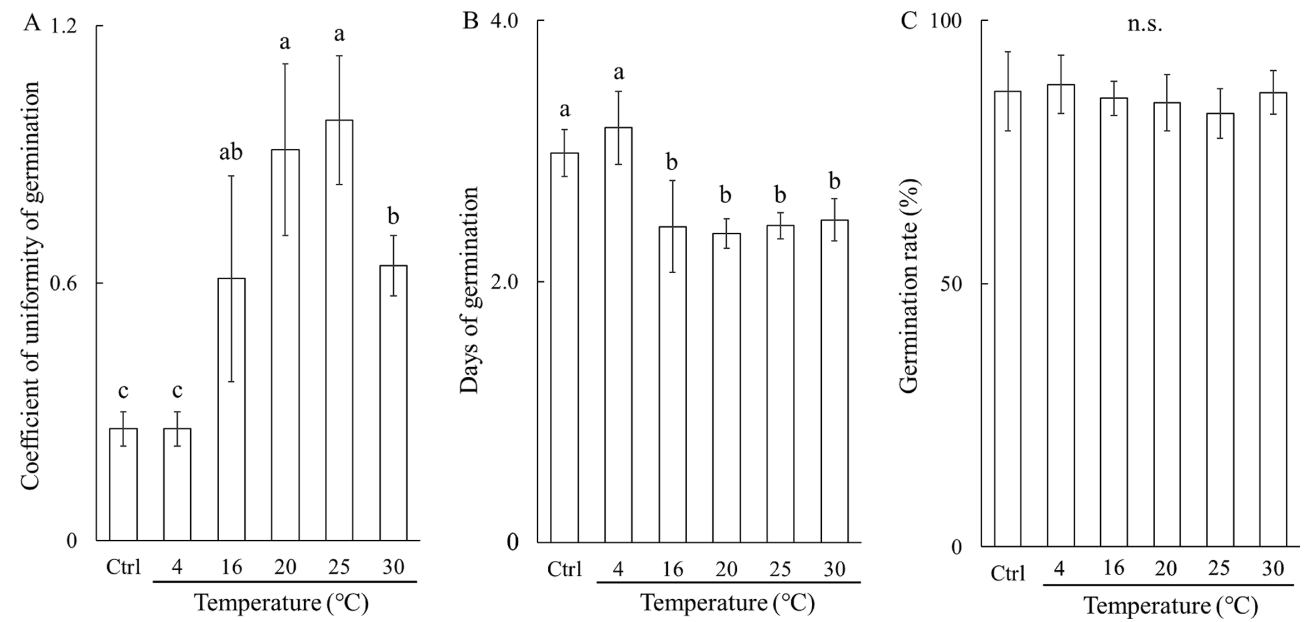

Fig. 2 Effect of water imbibing temperature on germination of Tartary buckwheat seeds.

Tartary buckwheat seeds were treated at various temperatures $\left(4,16,20,25\right.$, and $\left.30{ }^{\circ} \mathrm{C}\right)$ for 3 hr in tap water, to measure coefficients of uniformity (A), days of germination (B), and germination rate (C). Ctrl indicates control that was not applied imbibition treatment. Vertical bars indicate SD. Different letters indicate significant differences among treatments $(P<0.05$, Tukey HSD test), and n.s. indicates no significant difference. Experiments were performed at least three times. 
した. 新鮮重および乾物重は地上部（子葉および下肧軸） を微量電子天科でセルごとに測定した後, 総発芽個体数で 除し 1 個体あたりの重量を算出した. 乾物重は新鮮重測定 後の植物体を $80{ }^{\circ} \mathrm{C} に$ 設定した恒温乾燥機で 48 時間処理し た後に測定した. 本試験は, 1 セルにダッタンソバ種子を 30 粒播種し， 5 セル分の調査を 1 反復とした. また, 異なる播種 日で 3 回繰り返し試験を行った.

\section{5. 統計解析}

Fig. 1 および Fig. 2 のデー夕は Tukey 法により検定した. Fig. 3, Fig. 4 について F 検定を行ったところ, Fig. 3 は不等 分散であったことから Welch's $t$-testにより解析した. Fig. 4 は等分散であったことから Student's $t$-testにより解析した. 割合で示した結果はArc-sin 変換後に Tukey 法により解析 を行った. 有意差検定は $5 \%$ 水準とした.

\section{結果および考察}

\section{1. 種子への吸水処理がダッタンソバの発芽に与える影響}

未吸水処理区（対照）ならびに 1 時間, 3 時間, 6 時 間, 8 時間, 12 時間および 24 時間種子に吸水処理を行った 区の斉一発芽係数, 平均発芽日数, 最終発芽率の結果を Fig. 1に示した. 斉一発芽係数は未吸水処理区（対照）の 0.35 と比較して, 1 時間の区で 1.6 倍, 3 時間, 6 時間, 8 時 間, 12 時間, 24 時間の区で約 2 倍に上昇した. 一方で, 種 子に吸水処理を行った 6 区間に有意差はみられなかった (Fig. 1A). 平均発芽日数は, 未吸水処理区 (対照) の 2.7 日と比較して, 3 時間, 6 時間, 8 時間, 12 時間, 24 時間の 区で約 0.57 日有意に短縮された. 一方で, 1 時間の区と未 吸水処理区（対照）に有意差はみられなかった（Fig. 1B). 最終発芽率は未吸水処理区（対照）の $72.0 \%$ と比 較して, すべての区で有意差はみられなかった（Fig. 1C)。 次に, 未吸水処理区ならびに水温 $4{ }^{\circ} \mathrm{C}, 16{ }^{\circ} \mathrm{C}, 20{ }^{\circ} \mathrm{C}, 25$ ${ }^{\circ} \mathrm{C}, 30{ }^{\circ} \mathrm{C} て ゙ 3$ 時間種子に吸水処理を行った区の斉一発芽係 数, 平均発芽日数, 最終発芽率の結果を Fig. 2 に示した. 斉一発芽係数は, 未吸水処理区 (対照) の 0.26 と比較し て, $25^{\circ} \mathrm{C}$ ので 3.69 倍に上昇し最大となった.一方で, 30 ${ }^{\circ} \mathrm{C}$ のは $25^{\circ} \mathrm{C}$ のと比較すると 0.64 倍に減少した. また, 4 ${ }^{\circ} \mathrm{C}$ のと未吸水処理区（対照）に有意差はみられなかった (Fig. 2A). 平均発芽日数は未吸水処理区（対照）で 3.0 日 となり, $4{ }^{\circ} \mathrm{C}$ のと比較して有意差はみられなかった. また, 16 ${ }^{\circ} \mathrm{C}, 20^{\circ} \mathrm{C}, 25^{\circ} \mathrm{C}, 30{ }^{\circ} \mathrm{C}$ 区は平均 2.42 日となり, 未吸水処 理区（対照）および $4{ }^{\circ} \mathrm{C}$ のと比較して有意に短縮された (Fig. 2B). 最終発芽率は未吸水処理区の $81.4 \%$ と比較し て,すべての区で有意差はみられなかった（Fig. 2C).

イネやトウモロコシ, オオムギなどデンプン性種子の発芽が

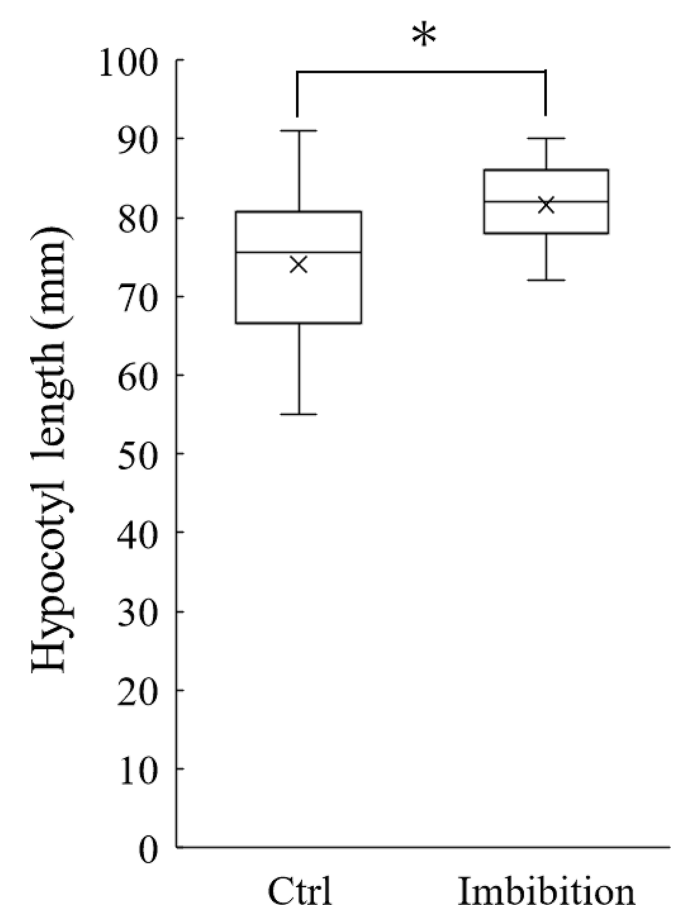

Fig. 3 Effect of seed imbibing treatment on hypocotyl length in Tartary buckwheat sprouts.

Tartary buckwheat seeds were treated with water $\left(25^{\circ} \mathrm{C}\right)$ for $3 \mathrm{hr}$ and grown under white light $\left(70 \mu \mathrm{mol} \mathrm{m}{ }^{-2} \mathrm{~s}^{-1}\right)$ for 8 days to measure the effect on hypocotyl length and dispersion of hypocotyl length. This data was analyzed in accordance with boxplot using 125 plants data (Ctrl) and 135 plants data (Imbibition). The cross symbol indicates averages of the data. Ctrl indicates control that was not applied imbibition treatment. Asterisks indicate significant differences among treatments $(P<$ 0.05 , Welch's $t$-test). Experiments were performed at least three times.

促進される要因の一つとして, 吸水を端緒としたデンプン分解 酵素の $\alpha$ アミラーゼの活性化 ${ }^{13)}$ やアブシシン酸 $(\mathrm{ABA})$ 代 謝酵素の活性化, ジベレリン $(\mathrm{GA})$ などの植物ホルモンの関 与が知られている ${ }^{14-16)}$. トマトでは種子に吸水処理を行うと, 約 12 時間後に細胞壁の軟化に関与する遺伝子の発現が誘 導され, シロイヌナズナでは種子への吸水処理を行うと 3 時 間, 6 時間, 12 時間後にジベレリン誘導性を示す遺伝子の 発現が誘導し, 発芽の準備が開始される ${ }^{17}$. ダッタンソバもデ ンプン性種子に分類されることから, 種子への吸水処理により 平均発芽日数が向上した要因として, GAによる $a$ アミラーゼ の活性化や $\mathrm{ABA} の$ 代謝などが促進された可能性が推察さ れた. また, 一般的に酵素には至適温度が存在する. 発芽 

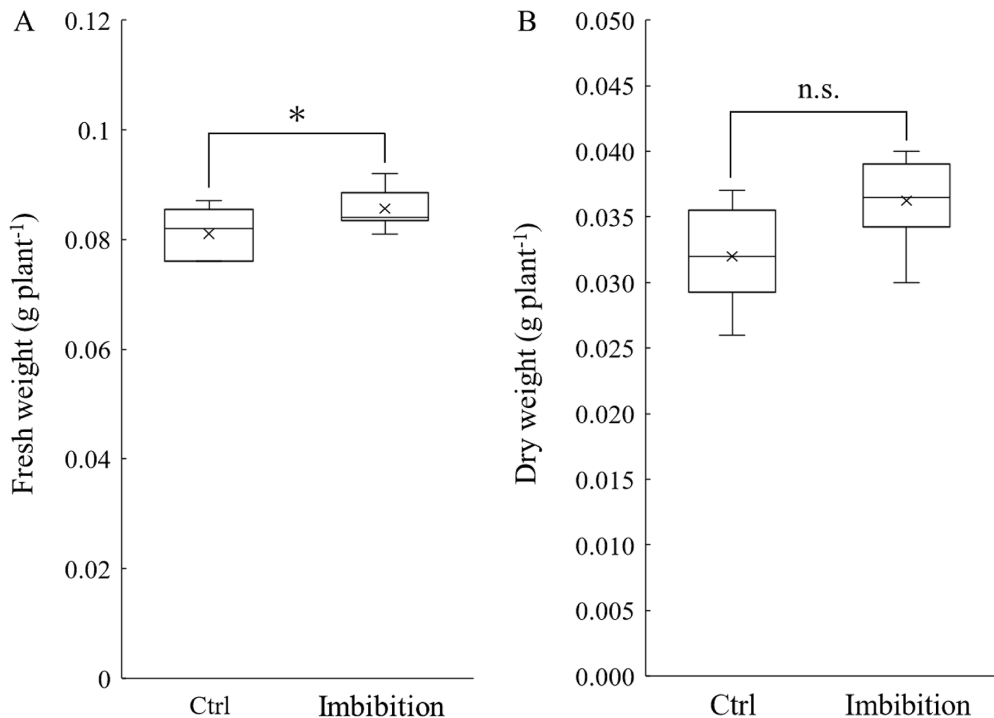

Fig. 4 Effect of imbibing treatment of seed on fresh and dry weights of Tartary buckwheat sprouts.

Tartary buckwheat seeds were treated with water $\left(25^{\circ} \mathrm{C}\right)$ for 3 hours and grown with white light $\left(70 \mu \mathrm{mol} \mathrm{m} \mathrm{m}^{-2} \mathrm{~s}^{-1}\right)$ for 8 days in order to measure the effect on plant fresh (A) and dry weight (B). Fig. 4A and $4 \mathrm{~B}$ were analyzed in accordance with boxplot using 125 plants (Ctrl) and 135 plants (Imbibition). The cross symbol indicates the average of each condition. Ctrl indicates control that was not applied imbibition treatment. Asterisks indicate significant differences among treatments $(P<0.05$, Student's $t$-test $)$, and n.s. indicates no significant difference. Experiments were performed at least three times.

適温は作物ごとに異なるため ${ }^{18-20)}$, 作物の生産において発 芽適温を解明することは非常に重要な知見になると考えられ る.これまでに, ダッタンソバ種子の発芽を改善するための吸 水処理に好適な水温やその処理時間については, 詳細な検 討は行われていなかった. 人工光型植物工場においてダッ夕 ンソバ種子の発芽を促進できる好適な種子への吸水温は 20 ${ }^{\circ} \mathrm{C} \sim 25{ }^{\circ} \mathrm{C}$ 付近にあり, $30{ }^{\circ} \mathrm{C}$ 超えると斉一発芽係数が低下 することおよびダッタンソバを発芽させる際は, 播種前に 3 時 間〜 24 時間吸水処理を行うと斉一発芽係数の向上や平均 発芽日数を短縮できることを解明した本研究成果は, 人工光 型植物工場におけるダッタンソバスプラウトの生産技術を開発 する際に有用な知見になると考えられる.

\section{2. 種子への吸水処理がダッタンソバスプラウトの成長に与え}

\section{る影響}

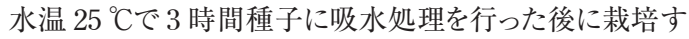
る区および未吸水処理区 (対照) の下肧軸長, 新鮮重, 乾 物重の結果をボックスプロットにより示した（Fig. 3, 4). 処理 区の下胚軸長の平均值は, 未吸水処理区（対照）の 74.1 $\mathrm{mm}$ と比較して $7.5 \mathrm{~mm}$ 有意に増加した. 次に処理区および
未吸水処理区（対照）の下胚軸長の分散を計算した. その 結果, 処理区は 1.09 , 未吸水処理区は 4.44 となり, 種子に 吸水処理を行うことで下肧軸長の分散は縮小された. また, 未吸水処理区 (対照) の第 3 四分点と第 1 四分点の差 (四分位範囲) は $14.3 \mathrm{~mm}$ であったのに対し, 処理区の四 分位範囲は $8.0 \mathrm{~mm}$ であった (Fig. 3). 処理区の新鮮重の 平均值は $0.08 \mathrm{~g}$ であり, 未吸水処理区 (対照) と比較して $0.006 \mathrm{~g}$ 有意に増加した. 一方で, $\mathrm{F}$ 検定により試験区間の 新鮮重の分散を比較したところ有意差はみられなかった. ま た, 未吸水処理区（対照）の最小值と第 1 四分点は同一 の值であった (Fig. 4A). 最後に, 処理区の乾物重は未吸 水処理区 (対照) と比較して, 平均值および分散に有意差 はみられなかった (Fig. 4B). 多くの種子内部にはデンプンや 脂質などが貯蔵されており, 発芽の促進に用いられる. トマト では, 細胞壁多糖類であるガラクトマンナンの分解に関与する タンパク質の遺伝子発現が吸水により誘導されることで, 発芽 が促進されると考えられている ${ }^{21,22)}$. ダッタンソバにおいても 種子に吸水処理を行なったことで, 早期に発芽が促進された 結果, 下胚軸の長さが増加したと推察された. また, 多くの植 
物において, 光合成を開始して間もない頃の芽生え期は水分 を吸収し種子や子葉に貯蔵された養分を代謝することで成長 を行っている ${ }^{23)}$. ダッタンソバ種子に吸水処理を行うと新鮮重 は有意に増加した一方で, 乾物重には有意差がみられなかっ た要因として, 栽培 8 日目のダッタンソバは光合成よりも種子 や子葉に貯蔵された養分を主に利用して成長している可能 性が考えられた。

\section{摘要}

スプラウト類は水と弱光で栽培可能なことから, 人工光型 植物工場での栽培に適合する可能性が高い. そこで本研究 では, 商業的にスプラウトとして生産されていない作物種から ダッタンソバ “満点きらり”を選定し, 種子への吸水処理（水 温, 時間）がスプラウト生産に重要となる発芽やダッタンソバ スプラウトの成長に与える影響を調查した. その結果, 未吸 水処理区（対照）と比較して $20^{\circ} \mathrm{C} \sim 25^{\circ} \mathrm{C}$ の水道水で種子 を 3 時間〜 24 時間吸水処理することで, 斉一発芽係数, 平 均発芽日数, 下肧軸長, 新鮮重が向上した. さらに, 下肧軸 長の分散が縮小された。一方で, 最終発芽率や乾物重には 影響はみられなかった. 以上の結果から, 人工光型植物工 場に押いてダッタンソバスプラウトを生産する際は, $20{ }^{\circ} \mathrm{C} \sim 25$ ${ }^{\circ} \mathrm{C}$ 水道水で種子を 3 時間〜 24 時間吸水処理することで, 栽培期間の短縮や発芽の斉一性の向上が望めると考えられ る.

\section{謝辞}

本研究遂行にあたり（国研）農研機構九州沖縄農業研 究センター園芸研究領域の大和陽一博士から研究に関する ご助言をいただいた. また, 松尾征徳氏, 永松万由美氏, 西 田道子氏にダッタンソバスプラウト栽培および研究調査のご協 力をいただいた.ここに深謝の意を表します。

\section{引用文献}

1) Takaya $Y$, Kondo $Y$, Furukawa $T$, Niwa M. Antioxidant constituents of radish sprout (Kaiwaredaikon), Raphanus sativus L. J. Agric. Food Chem. 51: 8061-8066. 2003.

2) Papi A, Orlandi M, Bartolini G, Barillari J, Iori R, Paolini M, Ferroni F, Fumo MG, Pedulli GF, Valgimigli L. Cytotoxic and antioxidant activity of 4-methylthio-3-butenyl isothiocyanate from Raphanus sativus L. (Kaiware daikon) sprouts. J. Agric. Food Chem. 56: 875-883. 2008.
3) Barillari J, Iori R, Papi A, Orlandi M, Bartolini G, Gabbanini S, Pedulli GF, Valgimigli L. Kaiware daikon (Raphanus sativus L.) extract: A naturally multipotent chemopreventive. Agent. J. Agric. Food Chem. 56: 7823-7830. 2008.

4) 澤井祐典, 沖智之, 西場洋一, 奥野成倫, 須田郁夫, 渡辺慎一. アブラナ科スプラウトのアスコルビン酸含量. 日本食品科学工学会誌. 61: 218-222. 2014.

5) 前田智雄, 前川健二郎, 戸田雅美, 大島千周, 角田英 男, 鈴木卓, 大澤勝次. ブロッコリースプラウトの生育お よびポリフェノール含量に及ぼす補光光質の影響. 植物 環境工学. 20: 83-89.2008.

6) Kim SJ, Kawaharada C, Suzuki T, Saito K, Hashimoto N, Takigawa S, Noda T, Matsuura-endo C, Yamauchi $\mathrm{H}$. Effect of natural light periods on rutin, free amino acid and vitamin $\mathrm{C}$ contents in the sprouts of common (Fagopyrum esculentum Moench) and tartary (F. tataricum Gaertn.) buckwheats. Food Sci. Technol. Res. 12: 199-205. 2006.

7) Seo JM, Arasu MV, Kim YB, Park SU, Kim SJ. Phenylalanine and LED lights enhance phenolic compound production in tartary buckwheat sprouts. Food Chem. 177: 204-213. 2015.

8) Kitazaki K, Watanabe S, Okamoto A, Matsuo M, Furuya S, Sameshima K. Far-red light enhances removal of pericarps in tartary buckwheat (Fagopyrum tataricum Gaertn.) sprout production under artificial lighting. Sci. Hortic. 185: 167-174. 2015.

9）久保摩希子, 萩原素之. ダイズ種子の吸水過程の簡便 評価法の検討と吸水状態と発芽成長の関係. In: 第 230 回日本作物学会講演会要旨. 資料集. 札幌. 9月 4 日 - 5 日. 348-349. 2010.

10）渡辺慎一, 松尾征德, 北崎一義, 鮫島國親, 澤井祐典, 諸岡譲, 篠崎正俊, 田中健一郎, 田中達也, 河野智謙, 吉田敏. 人工光型植物工場の簡易栽培システムにおけ る木材パルプ培地でのカイワレダイコン (Raphanus sativus L.) の生育拉よび一般生菌数. 植物環境工学. 28: 29-34. 2016.

11) Ranal AM, De Santana DG. How and why to measure the germination process? Rev. bras. Bot. 29: 1-11. 2006.

12）中村潤一, 沖陽子, 足立忠司. ツルヨシおよびセイコノヨ シの種子発芽特性. 雑草研究. 54: 21-24. 2009.

13) Beck E, Ziegler P. Biosynthesis and degradation of starch in higher plants. Annu. Rev. Plant Physiol. Plant Mol. Biol. 40: 95-117. 1989.

14) Kaneko M, Itoh $H$, Ueguchi-Tanaka M, Ashikari M, Matsuoka M. The $a$-amylase induction in endosperm during rice seed germination is caused by gibberellin synthesized in epithelium. Plant Phys. 128: 12641270. 2002.

15) Fincher GB. Molecular and cellular biology associated with endosperm mobilization in germinating cereal grains. Annu. Rev. Plant Physiol. 
Plant Mol. Biol. 40: 305-345. 1989.

16) Gubler F, Kalla R, Roberts JK, Jacobsen JV. Gibberellin-regulated expression of a myb gene in barley aleurone cells: evidence for MYB transactivation of a high-pI alpha-amylase gene promoter. Plant Cell. 7: 1879-1891. 1995.

17) Ogawa M, Hanada A, Yamauchi Y, Kuwahara A, Kamiya Y, Yamaguchi S. Gibberellin biosynthesis and response during arabidopsis seed germination. Plant Cell. 15: 1591-1604. 2003.

18）川上直人. 特集「時を超えて生きる一休眠のメカニズム とその応用一」種子の休眠・発芽と温度一発芽調節义 カニズムの解明をめざして一. 日本緑化工学会. 30 : 514-517. 2005.

19) Reynolds T, Thompson PA. Characteristics of the high temperature inhibition of germination of lettuce (Lactuca sativa). Physiol Plant. 24: 544-547. 1971.

20) Reddy LV, Metzger RJ, Ching TM. Effect of temperature on seed dormancy of wheat. Crop Sci. 25: 455-458. 1985.

21) Nonogaki H, Gee HO, Bradford JK. A germinationspecific endo-beta-mannanase gene is expressed in the micropylar endosperm cap of tomato seeds. Plant Phys. 123: 1235-1246. 2000.

22) Bewleyl JD. Seed germination and dormancy. Plant Cell. 9: 1055-1066. 1997.

23) 阿部信之, 橋本良二. 播種時におけるコナラ種子の乾 燥が芽生えの発達経過と成長量に及ぼす影響. 日本緑 化工学会. 33: 484-491. 2008. 